Research PAPER

\begin{abstract}
ADVANCE RESEARCH JOURNAL OF C $\mathbf{R}$ (6) $\mathbf{P}$ I M P R O V E M E N T Volume 7 | Issue 2 | December, 2016 | 224-230 $\bullet \bullet$ e ISSN-2231-640X

DOI :

10.15740/HAS/ARJCI/7.2/224-230

Visit us: www.researchjournal.co.in

\section{Genetic relationship assessment of superior accessions of Garcinia gummi-gutta L. collected from central Travancore region using RAPD markers}

Authors' Info

Associated Co-author : ${ }^{1}$ Regional Agricultural Research Station (K.A.U.) Kumarakom KOTTAYAM (KERALA) INDIA

Author for correspondence: ANU G. KRISHNAN Regional Agricultural Research Station (K.A.U.) Kumarakom KOTTAYAM (KERALA) INDIA Email: dranugk@gmail.com
ANU G. KRISHNAN, THUSHARA SUSAN SABU ${ }^{1}$, MADHUMOL JEEVAN ${ }^{1}$ AND GISHEENA GOPINATH ${ }^{1}$

\begin{abstract}
An experiment was conducted at Regional Agricultural Research Station, Kumarakom during 2014-15 with an objective to understand the genetic relationship of some superior Garcinia accessions having different geographic origin and maintained at germplasm collections of Regional Agricultural Research Station, Kumarakom, Kerala, India. Germplasm identification and characterization is an important link between conservation and utilization of plant genetic resources. In this study, random amplified polymorphic DNA (RAPD) markers were used to find out the genetic relationship of 30 garcinia accessions. This included two Garcinia varieties Amrutham and Haritham which were released during 2015 from this station. The primer OPM16 gave maximum number of polymorphic bands and OPAB 16 produced least. Out of the total 397 alleles scored, 68.76 per cent were found to be polymorphic. The polymorphic information content (PIC) ranged between 0.14 (OPC 7) and 0.49 (OPAB 16) and marker index (MI) ranged from 0.01 (OPC 7) to 0.15 (OPM 16 and OPAB 16) among the primers used. Jaccard's similarity co-efficient between genotypes ranged from 0.462 to 0.991 . An UPGMA dendrogram was constructed using NTSYS pc 2.02e software and showed two major clusters. The variety Amrutham did not form any cluster and stood alone in the group whereas Haritham clustered in the second group. This is the first report for the molecular based genetic diversity studies for these accessions.
\end{abstract}

KEY WORDS : Garcinia gummi-gutta, Genetic diversity, RAPD markers, Malabar tamarind

How to cite this paper : Krishnan, Anu G., Sabu, Thushara Susan, Jeevan, Mabhumol and Gopinath, Gisheena (2016). Genetic relationship assessment of superior accessions of Garcinia gummi-gutta L. collected from central Travancore region using RAPD markers. Adv. Res. J. Crop Improv., 7 (2) : 224-230, DOI : 10.15740/HAS/ARJCI/7.2/224-230.

Paper History : Received : 10.09.2016; Revised : 12.11.2016; Accepted : 26.11.2016 